\title{
KNOWLEDGE TRANSFER THROUGH INHERITANCE: SPIN- OUT GENERATION, DEVELOPMENT, AND SURVIVAL
}

\author{
RAJSHREE AGARWAL \\ University of Illinois at Urbana Champaign \\ RAJ ECHAMBADI \\ University of Central Florida \\ APRIL M. FRANCO \\ University of Iowa \\ MB SARKAR \\ University of Central Florida
}

\begin{abstract}
We investigated how the knowledge capabilities of industry incumbents affected the generation, development, and performance of "spin-outs" (entrepreneurial ventures of ex-employees). Analyses of 1977-97 data from the disk drive industry supported our hypothesis that incumbents with both strong technological and market pioneering know-how generate fewer spin-outs than firms with strength in only one of these areas. Also, an incumbent's capabilities at the time of a spin-out's founding positively affect the spin-out's knowledge capabilities and its probability of survival.
\end{abstract}

In certain high-technology industries, spinouts-a distinctive class of entrepreneurial entrants that inherit knowledge from industry incumbents through their founders-are not only legion, but are also major innovators. Spin-outs (entrepreneurial ventures by ex-employees of an incumbent firm) are widespread in industries such as semiconductors (Braun \& MacDonald, 1978), disk drives (Christensen, 1993), and lasers (Klepper \& Sleeper, 2000). Fairchild Semiconductor's many spin-outs (dubbed "Fairchildren" [Klepper, 2001]) are a salient example. Founded by former employees of an incumbent firm, these stand-alone entrepreneurial ventures compete in the same industry as the parent but have no equity relationships with any in-

All the authors contributed equally. Our names are arranged in alphabetical order. We thank Gautam Ahuja, Inigo Arroniz, Donald Bergh, Glenn Hoetker, Junsoo Lee, Bisakha Sen, Sidney Winter, and three anonymous reviewers for helpful comments. We also appreciate the input received from seminar participants at the University of Central Florida, Cornell University, the Georgia Institute of Technology, the Harvard Business School, the University of Houston, the University of Illinois at Urbana Champaign, the University of Michigan, the University of Minnesota, the Ohio State University, Purdue University, the University of North Carolina at ChapelHill, the Wharton School's technology miniconference, and the ZEW entrepreneurship workshop. The usual disclaimer applies. cumbent. Operating at the forefront of innovation, spin-outs pose a special threat to incumbents since they can capitalize on knowledge gained from discoveries made during the course of their founders' employment in incumbent firms (Bhide, 2000). Since spin-outs are a new topic for management research, we attempted to systematically examine some fundamental questions that are key to developing a theory-based understanding of spin-outs: What types of firms are most likely to generate spin-outs? Is there a knowledge legacy that links incumbent parents to spin-outs? What are the implications of such heritage?

Our study builds on existing research that has studied how historical antecedents affect entrants' resource heterogeneity. For example, there is evidence that experience within existing markets shapes a firm's knowledge resources and therefore influences performance in markets into which the firm diversifies (Carroll, Bigelow, Seidal, \& Tsai, 1996; Klepper \& Simons, 2000; Nelson \& Winter, 1982). Research has also suggested that routines and resources transfer from old to new organizations through personnel migration (Aldrich \& Pfeffer, 1976; Almeida \& Kogut, 1999; Pfeffer \& Leblebici, 1973). Thus, it is suggested that prior employment affiliations may influence not only new venture formation (Burton, Søorensen, \& Beckman, 2002; Shane \& Khurana, 1999), but also product-market strategies (Boeker, 1997) and firm survival (Bruderl, 
Preisendorfer, \& Ziegler, 1992; Phillips, 2002). However, despite evidence that preentry experience matters and that new firm know-how may originate in older firms (Stinchcombe, 1965), a few significant gaps remain in researchers' understanding of the birth and development of knowledge-based capabilities in new ventures (Helfat \& Lieberman, 2002; Zahra, Ireland, \& Hitt, 2000).

First, although there is some evidence that knowledge-rich firms tend to be "entrepreneurial hotbeds" and more prone to spawning spin-outs (Burton et al., 2002; Franco \& Filson, 2000; Garvin, 1983), this relationship is underdeveloped in the literature, both conceptually and empirically. Does abundant knowledge per se lead to employee entrepreneurship, or is it contingent on a firm's use of its know-how? Given that the values of different types of know-how may be interdependent (Moran \& Ghoshal, 1999; Teece, 1986), the impact of a firm's organization of its know-how on employee entrepreneurship may be more complex than hitherto supposed. Second, past authors have assumed an underlying process of knowledge inheritance by a progeny firm, without explicitly testing whether inheritance from an incumbent parent actually occurs (e.g., Phillips, 2002). Therefore, it is unclear whether knowledge is in fact inherited, and how preentry affiliation with an incumbent shapes a start-up's knowledge endowments. Third, little research has systematically linked inherited knowledge to organizational outcomes (Huber, 1991). It is not clear whether the imprinting effects of initial knowledge endowments persist, or whether they affect organizational learning over time. In addition, there has been very little scrutiny of how employee entrepreneurship as the agent of tacit know-how affects the "stickiness" of knowledge transfer (Szulanski, 1996) and therefore its internalization within a progeny firm. Finally, little is known about how the preentry incumbent affiliation of entrepreneurial firms affects survival.

In this study, we addressed the above gaps by developing and testing a theoretical framework linking knowledge inheritance to spin-out formation, development, and survival. We considered two specific types of know-how, namely, technological and market pioneering, which form the bases of innovation and marketing-based differentiation. It is generally believed that these capabilities underlie strategic renewal in high-technology markets, where frequent technological disruptions create new opportunities alongside obsolescence (Cohen \& Levinthal, 1990; Daneels, 2002; Teece, Pisano, \& Shuen, 1997). We used data on the rigid disk drive industry, the "fruit fly of industries," so called because of its rapid technological changes (Christensen, 1993). Since spin-outs constitute a significant percentage of new entrants in this industry, it was a particularly appropriate setting for our study.

Our article thus contributes new work on an underresearched phenomenon. By suggesting that the organization of capabilities may be as important a source of performance heterogeneity as the capabilities themselves, our research advances understanding of the "resource-based view" (Barney, 1991; Wernerfelt, 1984) of the firm. Our study also contributes to emerging ideas surrounding strategic entrepreneurship (Hitt, Ireland, Camp, \& Sexton, 2001). Further, we add to the entrepreneurship literature by investigating the impact of both entrepreneurial flexibility and resources inherited through the preentry experience of founders on new venture performance.

\section{KNOWLEDGE INHERITANCE THROUGH EMPLOYEE ENTREPRENEURSHIP}

According to a knowledge-based perspective, the underlying principle of organization is the generation, combination-recombination, and exploitation of knowledge (Conner \& Prahalad, 1996; Kogut \& Zander, 1996). In particular, the focus is on tacit knowledge that is acquired largely through personal experience, such as learning by doing or by observing (Nonaka, 1994). Knowledge possessed within an existing organization is typically viewed through the lens of competitive advantage (Barney, 1991; Grant, 1996). New knowledge that results from technological breakthroughs or customer insights, however, is also the fountainhead of new firm entry (Gort \& Klepper, 1982; Schumpeter, 1934). Since knowledge is potentially appropriable by individuals that possess it (Arrow, 1962), employees of incumbent firms are in a position to start their own ventures using new knowledge created through incumbent investments. Thus, the potential for employee entrepreneurship results from incumbent firms being imperfect and permeable repositories of knowledge and causes new organizations to emerge from other organizations (Stinchcombe, 1965). Moreover, the effect of lineage may extend beyond formation, as the transfer of rules, routines, and procedures from parent to progeny organizations both constrains and empowers the new firms (Brittain \& Freeman, 1986; Romanelli, 1991). However, there is a void in scholars' understanding of the forces governing spin-out formation and evolution, as conceptual and empirical research in this area is still underdeveloped. Extant work can be categorized into three research 
streams: knowledge spillovers as the source of new firm formation, inherited knowledge as the source of new firm know-how, and the impact of genesis on new firm outcome. We briefly review these three theoretical streams since they form the basis for our hypotheses relating to spin-out generation, development, and survival.

The first research stream, on knowledge spillovers through employee mobility, has focused on the threat of voluntary exits from firms of experts who possess critical know-how, a threat causing technology-rich firms to be known as "precarious monopolies" (Stinchcombe \& Heimer, 1988; Zucker, Darby, \& Brewer, 1998). A firm's tacit knowledge is not only team-based and socially embedded in routines (Nelson \& Winter, 1982), but also resident in individual human capital (Berman, Down, \& Hill, 2002; Hitt, Bierman, Shimizu, \& Kochhar, 2001; Lepak \& Snell, 1999; Szulanski, 1996). As employees internalize an organization's culture (Inzerille \& Rosen, 1983; Meek, 1988), they imbibe procedural and declarative knowledge related to functional capabilities such as R\&D and marketing. Human capital is mobile since employees are under limited organizational control and free to quit at will (Aldrich \& Pfeffer, 1976; Boeker, 1997; Coff, 1997). Owing to inherent difficulties in detecting knowledge expropriation (Arrow, 1962) and the limited effectiveness of market mechanisms in protecting knowledge (Liebeskind 1996), employees may leave and expropriate their employer's know-how. Although firms can increase employees' exit costs and impose "golden handcuffs" (Liebeskind, 1996), these incentive mechanisms are subject to agency costs. "Moral hazard" (Wiggins, 1995) and "information asymmetry" (Anton \& Yao, 1995) create contractual problems between employees and their employers. As a result, incentives provided by incumbent firms to lock in their employees (and their knowledge) may not be effective because the potential rewards to the employees are greater in entrepreneurial ventures. These studies therefore have suggested that a genealogical knowledge-based framework may explain new venture formation.

Researchers pursuing a related stream of research have focused on knowledge transfer from a recipient organization's perspective and investigated knowledge diffusion and the interorganizational social structure created by executive migration (Aldrich \& Pfeffer, 1976; Boeker, 1997). Various difficulties involved in the transfer of "sticky" tacit knowledge have been acknowledged (von Hippel, 1994), but research has emphasized that organizational blueprints can transfer across firm boundaries, in a manner analogous to the reproduction and transmission of biological genes (Winter, 1991). These transfers may include unique insights and decision rules used to transform resources into action (Prahalad \& Bettis, 1986), cognitive dimensions of competency (Fiol, 1991), and specific knowledge and information (Boeker, 1997). Since "what an organization knows at its birth will determine what it searches for, what it experiences, and how it interprets what it encounters" (Huber, 1991: 91), one implication is that a spin-out's capability accumulation may be linked to its inherited knowledge and that the agent of transfer may have an impact on the efficacy of transfer.

Finally, heterogeneity in entrant capabilities has been related to the prior affiliation and preentry knowledge of firms (Carroll et al., 1996; Helfat \& Lieberman, 2002; Klepper \& Simons, 2000). Other work has also suggested that entrepreneurial origin is an important source of resource differences, strategies, and performance (Knight, 1989; McGrath \& MacMillan, 2000; Shrader \& Simon, 1997). Therefore, entrepreneurial origin combined with prior founder affiliation may have different survival implications for spin-outs than for other entrants.

Each of the research streams outlined above provides a foundation for theorizing about the knowledge relationships between incumbent parents and their spin-outs, the knowledge relationships between spin-outs and other entrants, and organizational life chances. In developing our hypotheses, we integrated these theoretical perspectives and related them to spin-out generation, inheritance, and performance.

\section{Incumbent Knowledge and Spin-out Generation}

As firms face the frequent disruptions that characterize high-technology markets, their ability to seize new opportunities or withstand threats of obsolescence depends on their capacity to reconfigure resources "ahead of competitors." That capacity in turn depends on their R\&D and marketing-related capabilities (Daneels, 2002; Teece, 1986). The potential value of a firm's R\&D efforts can be unlocked and appropriated in the marketplace by understanding and satisfying new customer needs quickly (Jaworski \& Kohli, 1993; Narver \& Slater, 1990). Thus, while a firm's technological knowhow reflects its ability to generate new scientific discoveries and technological breakthroughs, its market pioneering know-how indicates whether it can commercialize technological innovations before competitors do. The ability to pioneer markets is especially critical in markets with short product life cycles, where prices tend to drop sharply after an initial period (Hatch \& Macher, 2002). The two 
capabilities are thus complementary: technological innovations need to be transformed into "killer applications" before a firm can reap the rewards of its R\&D capabilities (Cohen \& Levinthal, 1990; Moran \& Ghoshal, 1999; Teece, 1986).

Firms with abundant know-how in either dimension are likely to be associated with a higher potential to generate spin-outs. First, the place of employment may influence an employee's ability to perceive an entrepreneurial prospect. Employees of firms with abundant knowledge may possess unique and idiosyncratic information that enables them to discover potential opportunities ahead of others. Since knowledge asymmetry lies at the heart of entrepreneurship, such access to valuable knowledge can be a source of advantage (Venkataraman, 1997). Working with firms at the cutting edge may help to create a "knowledge corridor" that facilitates opportunity recognition by enhancing the ability to understand, infer, and creatively extend knowledge in new ways (Roberts, 1991). Further, the quality of research discussions and social interactions is likely to be substantively different in a premier research institution from what it is in others. Scientists have been known to undergo short-term financial sacrifices to apprentice for firms that are on the technological frontier and thus enhance their knowledge (Franco \& Filson, 2000; Hitt, Bierman, Shimizu, \& Kochhar, 2001). Since exploiting an opportunity in the market is dependent on discovering it, and the discovery of new entrepreneurial opportunities may be triggered by prior information and existing capabilities (Shane, 2000), employees at firms that are at the cutting edge of know-how may be more likely to perceive entrepreneurial opportunities.

Second, affiliation benefits may make it easier for employees of leading firms to raise the financial and other resources needed to start new ventures. Raising capital is a process that is fraught with information asymmetry between provider and recipient (Brav \& Gompers, 1997). The newer the technology and the more nascent the market, the greater the information asymmetry and associated uncertainty about a venture's prospects. In the absence of unambiguous quality measures, investors depend on certification cues in making judgments. Such cues can emanate from institutional affiliations (Gompers \& Lerner, 2001; Shane \& Khurana, 1999). Affiliation with a high-status organization influences not only perceptions of employees' skills and trustworthiness (Davis, 1991; Eisenhardt \& Schoonhoven, 1996), but also perceptions of the importance of innovations in emerging areas of technology (Podolny \& Stuart, 1995). Would-be founders' prior employment with a "marquee firm" transfers status and legitimizes a new venture (Podolny, 1994; Stuart, Hoang, \& Hybels, 1999). Employees of knowledge-rich firms thus benefit from enhanced "entrepreneurial capital" (Aldrich, Renzulli, \& Langton, 1998), which facilitates mobilization of the resources necessary to undertake an entrepreneurial venture (Burton et al., 2002; Higgins \& Gulati, 2003). As a result, the place of prior employment can influence access not only to opportunities but also to resources (Granovetter, 1985).

Thus, firms with abundant knowledge may be more prone to creating spin-outs because opportunity recognition and investor confidence are heightened. We suggest, however, that whether employees act on these potential opportunities and undertake the entrepreneurial act is likely to depend on how well incumbent firms utilize their knowledge. When an organization's strategy emphasizes either technological know-how or market pioneering know-how, identified but unexploited opportunities result. New scientific breakthroughs that are not commercialized and marketing insights into emerging and unfulfilled customer needs that are not met with technological breakthroughs are both symptomatic of underexploited know-how. We suggest two reasons why it is not abundant knowledge as such that creates spin-outs, as past research has suggested (Garvin, 1983), but the manner in which a company uses such knowledge.

First, when firms do not simultaneously develop their technological and market pioneering knowhow, they are likely to create frustration among their employees, who perceive their organization as systematically missing out on either value-creating or value-appropriating opportunities. For example, Christensen (1993) showed how a firm's dependence on existing customers not only hampered efforts to reorient market strategies, but frustrated engineers whose technological inventions were not commercialized. When firms develop promising technological inventions but fail to marshal the commitment to take the technologies to market, their behavioral inertia and inaction may result in a growing gap between employees' aspirations and their current prospects within the firms (Kahneman \& Tversky, 1979). Such divergence in organizational and individual goals may lower job satisfaction and increase employee turnover (Benkhoff, 1997) as well as employees' risk propensity (Greve, 1998) and their desire to venture out on their own. On the other hand, by using their know-how and responding to technological and market-pioneering opportunities, organizations prevent the aggravation and frustration that builds up among scientists and other professional employees when they per- 
ceive their ideas and inventions are being shelved (Christensen, 1993; Garvin, 1983). For firms that invest in both know-how dimensions concurrently, the complementarity of technological and market pioneering know-how (Griffin \& Hauser, 1996; Teece, 1986) not only creates a valuable synergy, but also, by aligning organizational and individual goals, reduces frustration, thereby inhibiting employee entrepreneurship.

Second, the perception of available opportunities for profitable entrepreneurial entry may also be related to whether or not an incumbent organization exploits its know-how. Noncommercialized technologies and unexploited market opportunities, particularly those that are substantial and path-breaking, increase employees' confidence about venturing out, and thus their entrepreneurial propensity (Eisenhardt, 1989). On the other hand, incumbent organizations that possess both highend technological and market pioneering knowhow exhibit a "willingness to cannibalize" (Chandy \& Tellis, 1998; Kamien \& Schwartz, 1982). Thus, an incumbent's unwillingness to pursue certain technologies may cause employees to perceive abundant entrepreneurial opportunities and hence lower entry and survival barriers for their own ventures, while preemptive incumbent entry into an emerging niche or technological subfield may deter spin-out formation by restricting the availability of attractive opportunities.

In summary, given its effect on both internal employee motivation and external market opportunities, we propose that although an abundance of underutilized knowledge can beget spin-outs, such incidents are deterred when the knowledge of a firm is put to use. ${ }^{1}$ We accordingly hypothesize:

Hypothesis 1. Increases in either technological or market pioneering know-how enhance the likelihood of spin-out generation; however, increases in both technological and market pioneering know-how decrease this likelihood.

\section{Inherited Knowledge as a Source of Spin-out Knowledge}

Organizational sociologists have theorized about the interorganizational transfer of routines and resources (Brittain \& Freeman, 1980; Hannan \& Freeman, 1986). Such routines find expression in not only R\&D functions and marketing strategy, but also in idiosyncratic knowledge about technologies and customers (Thompson, 1967). Moreover, a

\footnotetext{
${ }^{1}$ We would like to thank an anonymous reviewer for helping us articulate this thought.
}

complex and critical part of technology and marketing know-how is their "softer" side, which goes beyond codified knowledge available in scientific papers, formulae, technical specifications, blueprints, strategy reports, and hardware and is held by individual employees in the form of tacit knowledge and competence assets (Kogut \& Zander, 1992; Teece, 1988). When employees leave to start new ventures, they walk out with tacit knowledge. Intimate knowledge about technology and markets can transfer across organizations from an incumbent parent to a spin-out through founders. The initial knowledge endowment of a spin-out will then be connected to the parent's knowledge at the time the founder worked with the incumbent.

This initial stock of inherited knowledge (Huber, 1991) is likely to have long-term effects on a spinout. According to Stinchcombe (1965), founding conditions "imprint" an organization on various levels-including its structure, strategy, technology, routines, and culture (Sastry \& Coen, 2000)— and continue to have long-term effects. Further, an organization's absorptive capacity (its ability, efficiency, and aspiration to learn, discover, and acquire new knowledge) is also linked to its level of prior related knowledge (Cohen \& Levinthal, 1990). Differences in initial endowments may position firms on heterogeneous developmental paths (Shane \& Stuart, 2002), thus implying that inherited knowledge may be related to a spin-out's knowledge accumulation over time. Simply put, smart parents are likely to have smart progeny. Since starting with a good model can affect subsequent firm performance (Cyert, Kumar, \& Williams, 1993), superior knowledge endowments at birth can result in longer-term knowledge superiority. Thus,

Hypothesis 2. The levels of a spin-out firm's (a) technological and (b) market pioneering knowhow over time will be positively related to the level of its parent's (a) technological and (b) market pioneering know-how, respectively, at the time of the spin-out's inception.

\section{Spin-out Knowledge Capabilities and Survival}

Owing to their inherited knowledge and entrepreneurial origin, spin-outs may differ in their knowledge and survival probabilities from other entrants. We used Helfat and Lieberman's (2002) refinement of a coarse-grained distinction between de novo and de alio entrants based on pre-entry experience (Carroll et al. 1996; Klepper \& Simons, 2000). Among entrepreneurial de novo entrants, we distinguished between spin-outs and non-spin- 
outs, since spin-outs inherit knowledge from an industry incumbent. Among de alio entrants, we distinguished between diversifying entrants and incumbent-backed ventures. Diversifying entrants are established firms in other industries that enter a focal industry. Incumbent-backed ventures represent separate legal entities with ties to incumbent firms (such as subsidiaries, joint ventures, franchisees, and spin-offs). ${ }^{2}$

Entrant knowledge capabilities. Among the four types of entrants, both incumbent-backed ventures and spin-outs benefit from direct knowledge transfers from incumbents. Just as spin-outs inherit knowledge from parent firms through founders, incumbent-backed ventures obtain knowledge through cooperative relationships with the incumbents at birth, and perhaps on a continuing basis. Thus, given their links to incumbents, we did not hypothesize any knowledge difference between these two groups, leaving the matter as an empirical issue. Diversifying and non-spin-out de novo entrants, however, learn either by doing or by indirect "grafts," such as recruiting employees who work in the relevant industry (Boeker, 1997; DiMaggio \& Powell, 1983). We argue that, compared with these two entrant types, spin-outs have an advantage, because the agents of knowledge transfer are founders as opposed to recruited employees. We base our hypothesis on the premise that founders can realize a more effective transfer of sticky knowledge (von Hippel, 1994; Szulanski, 1996) to their organizations than can hired employees who lack such a pivotal role.

Knowledge is said to be sticky if organizations encounter difficulties in its internal transfer (von Hippel, 1994). Stickiness results from the additional costs incurred during the adoption of complex technology and business processes, which involve their conscious reconstruction, diffusion, and integration into new routines within an organization. Such stickiness causes knowledge, particularly its tacit component, to lie inert in some part of an organization-acquired, yet not readily accessible or retrievable, and therefore not deployable and convertible into value when required (Whitehead, 1929). As a result, "organizations may not necessarily know all that they know" (Szulanski, 2000: 10) and fall short of fully exploiting their know-how (von Hippel, 1994).

\footnotetext{
${ }^{2}$ Incumbent-backed ventures are hybrids, part diversifying and part de novo entrant. The existing firm that backs such a venture may have a financial stake in it, or board of director representation, but it is a new company and a separate legal entity (Helfat \& Lieberman, 2002).
}

We posit that the directness of knowledge transfer through employee-founders reduces stickiness and increases a firm's ability to integrate and successfully acquire knowledge. First, the general management role of entrepreneurial founders enables them to have a holistic picture. Employees recruited from incumbents may have limited ability to transfer relevant resources across different departments of a new organization. Further, their functional identification may actually decrease information dissemination through the organization (Fisher, Maltz, \& Jaworski, 1997). Acting as knowledge brokers between functional domains and various employees, founders, on the other hand, can increase the likelihood of employees adopting a new practice (Lenox \& King, 2003). By being in a more influential position to bring about progressive routinization of "best practices," founders have an advantage over hired lower-level employees in effecting the transfer of knowledge that they bring into firms. Second, founders have incentives and the motivation to share their knowledge and transform it into best practices, so as to appropriate full benefits from their know-how, but employees may be subject to agency problems and competitive incentive structures that can create exchange dynamics in internal knowledge markets that discourage sharing knowledge (Davenport \& Prusak, 1998). Since power in an organization depends on having nonreplicated knowledge, employees may prefer not to lose their knowledge monopolies. Founders face no such divergence between their own and an organization's goals, causing useful knowledge to be disseminated within the organization more easily.

Finally, the founding teams of spin-outs are likely to have knowledge advantages over employees hired individually into new firms. Typically, multiple employees from diverse backgrounds or firms come together to start a new firm. Armed with insider industry knowledge, ex-employee founders are likely to conduct active and more fruitful searches than other founders or entrants for specific pockets of complementary knowledge in their former employing firms or their social networks in an industry to create synergy among the individual components of know-how. This synergy increases the potential value of their combined know-how (Dess \& Shaw, 2001) in spin-outs. Owing to the availability of industry-specific information through prior industry affiliation, spin-outs have a knowledge advantage over other entrants. Accordingly,

Hypothesis 3. Spin-outs will have higher levels of (a) technological know-how and (b) market 
pioneering know-how than both non-spin-out de novo and diversifying entrants.

Entrant survival. Spin-outs, as an organizational form that represents employee entrepreneurship, may also be advantaged over other types of entrants on a key dimension of performance, namely, survival. Spin-outs have both inside knowledge of their industry, and entrepreneurial origin, which has been argued to be an important source of resource differences, strategies, and performance (Knight, 1989; Shrader \& Simon, 1997). Each dimension, we posit, gives spin-outs survival advantages over the other three entrant groups.

Spin-outs, just like non-spin-out de novo entrants, are entrepreneurial entrants. However, they also have the benefit of insider status, which means that their initial resource endowments are likely to be superior to those of other de novo firms. In addition to having technological and marketing knowledge, spin-out founders are likely to benefit from their previous employer's contacts and from network ties (Higgins \& Gulati, 2003; Yli-Renko, Autio, \& Sapienza, 2001). Further, spin-outs are likely to bring in routines and processes and links with customers that enable them to better overcome liabilities of newness (Phillips, 2002). In addition, as Shane and Stuart (2002) found, founders' social capital is positively related to survival. While all founders may bring in some social capital, the social capital of spin-out founders is likely to be more closely related to the industry that they operate in and, therefore, more valuable than the social capital of those who lack prior incumbent affiliation. Thus, in keeping with the findings of Phillips (2002), we expected spin-out firms to have a survival advantage over other de novo entrants.

Relative to diversifying entrants, spin-out firms are advantaged in terms of both their founders' access to industry-related information and their entrepreneurial origin. While diversifying entrants may have access to resources and capital, these resources may not be as directly related to the focal industry as the resources garnered by spin-out firms through their own networks and social capital. Higher autonomy, lack of bureaucratic inertia, and simple structures enable entrepreneurial spin-outs to creatively combine and exchange resources more quickly than diversifying entrants. Diversifying entrants frequently suffer from conflicting signals and role confusion stemming from vested interests in the established organizations that are creating them (Haveman, 1992), and the entrants' managers may face a variety of political and corporate objectives that pull them in different directions. Corporate authority and the need to obtain clearance on strategic decisions may create organizational inertia in diversifying entrants, giving spin-outs a learning advantage in dynamic environments (Carroll et al., 1996), since they can move more quickly and decisively to deploy new knowledge routines (Rosenbloom \& Christensen, 1994). The managers of diversifying entrants are likely to be evaluated on the basis of how closely they adhere to a corporate plan, but spin-out founders are motivated by the ends achieved, because their livelihood is tied to their ventures' performance. Thus, relative to diversifying entrants too, spin-out firms should have a survival advantage.

Finally, compared with incumbent-backed ventures, spin-outs lack parental support. It may seem that parental backing, in cushioning the liability of newness, advantages incumbentbacked ventures. However, this advantage may be slight for two reasons. First, continued parental involvement may result in the same organizational inertia among incumbent-backed ventures that is faced by diversifying entrants. Second, underutilization of knowledge resources by incumbents may set into play certain self-selection processes whereby the characteristics of employees that venture out on their own work in favor of spin-outs. Research has revealed that an entrepreneurial mind-set may be distinct from a managerial one (McGrath \& MacMillan 2000). Entrepreneurs tend to have a higher risk-taking propensity, lower uncertainty avoidance, and a preference for innovative behavior (Carland, Carland, \& Stewart, 1996; Drucker, 1995). These are traits that match the requirements of hightechnology markets (Moriarty \& Kosnik, 1989). Further, expectations of success are linked to the choice of undertaking an entrepreneurial venture, and individuals' expectations of success through entrepreneurship are related to their assessments of personal capabilities and to accessible resources and earlier investments in relevant resources (Blumberg \& Pfann, 2001). Therefore, as incumbents fail to utilize opportunities, it is those employees with entrepreneurial capital and ability who are likely to depart and form spin-outs. Spin-outs, manned by personnel with greater entrepreneurial zeal and ability than other entrants, may thus ultimately fare better than incumbent-backed ventures. Therefore,

Hypothesis 4. The likelihood of survival will be greater for spin-out entrants than for all other types of entrants. 


\section{METHODS}

\section{Context: The Rigid Disk Drive Industry}

We tested our hypotheses using data from the rigid disk drive industry from 1977 to 1997. Disk drives are magnetic information storage devices used in computers. The industry is a particularly appropriate setting owing to its rapid pace of technological evolution, which is detailed below, and its large number of entrants, of which a high percentage were spin-outs. (See Christensen [1993, 1997] for a detailed industry history.)

The availability of longitudinal data is a chief constraint to studies such as ours. To maintain accuracy, particularly on firms' early histories, we collected data from sources that documented facts about firms and the industry at the time of occurrence and tracked information on important historical events in the industry for all firms entering and exiting the market. As have a number of past researchers (Christensen, 1993; King \& Tucci, 2002; Lerner, 1997), we used information compiled from the Disk/Trend Report, a market research publication that has covered the disk drive industry since 1977. We identified the existence and type of preentry affiliation of all entering firms, and in particular determined parent-progeny relationships for spin-outs, using background information on the founders of new firms from the Disk/Trend Report. Company press reports and news releases and various technological sources, scientific journals, books, articles in periodicals, chronologies, and directories (for instance, the Directory of Corporate Affiliations and the International Directory of Company Histories) were used to supplement. The database included all firms in the industry during 1977-97 for which we found information on the introduction times of new products within the industry, product characteristics, and annual sales of disk drives. Since every productive firm, regardless of size, was included for its span of existence in the market, our sample does not suffer from a survival bias.

\section{Pace of Technological Change in the Disk Drive Industry}

In 1973, IBM pioneered the 14-inch Winchester, the first completely sealed and removable disk drive, and the disk drive industry experienced numerous innovations in the following 20 years. Architectural innovations resulted in five new subsequent diameters and created new submarkets (the 8 -inch in 1979, the 5.25-inch in 1980, the 3.75-inch in 1983, the 2.5-inch in 1988, and the 1.8-inch in 1991). In addition to these disruptive innovations, within each diameter, several modular and incremental innovations resulted in dramatic increases in "areal density," defined as the megabytes of information that can be stored on a square inch of a particular drive. Enabling cross-diameter comparisons, areal density is generally used as an industry standard to determine a drive's technological advancement. The main product performance measure for drives, it represents a combination of technologies-access speed, head technology, and recording technology. Research groups within disk drive firms report that increasing storage capacity is the key challenge and focus of their technological activities. Figure 1 shows the rapid technological evolution in the industry over the years, within and across diameters. The diameter-specific curves represent the highest density drive produced in the industry within each diameter in a given year and thus the technology frontier specific to the particular diameter. The highest-areal-density curve represents the highest-density drive produced in the industry in a particular year across all diameters. Both 14-inch and 8-inch diameters experienced a withdrawal from the market during this period. The dominance of newer diameters over time is evidenced by the fact that the highest areal density of the 14-inch drive was overshadowed by that of the 5.25-inch drive in 1987, which in turn was overtaken by the 3.5 -inch in 1988, and the 2.5 -inch in 1997.

\section{Types of Entrants into the Disk Drive Industry}

In response to profit opportunities from such rapid technological dynamism and market growth, substantial market entry occurred for the first ten years of the period studied, followed by an industry shake-out in 1986. In addition to 39 incumbents that entered between 1973 and 1976, there were 153 new entrants after 1977. Under the general definitions from Helfat and Lieberman (2002), entrants into the disk drive industry can be grouped into four categories. Spin-outs, the first group of entrants, represent an important mechanism of knowledge diffusion and technology transfer in this industry. We defined a spin-out as a firm started by individuals who were employees of existing firms in the industry (incumbent firms) in the year prior to the spin-outs' formation. Of the entrants in the period studied, $40(25 \%)$ were spinouts. Checks ensured that there were no formal connections between the parents and the spin-outs. The mean number of ex-employee founders per spin-out was 2.47 (s.d. $=1.5$ ), indicating that, on average, groups of ex-employees founded spinouts. The founders of the spin-outs were all senior- 
FIGURE 1

Areal Density $^{a}$ of Drives by Diameter
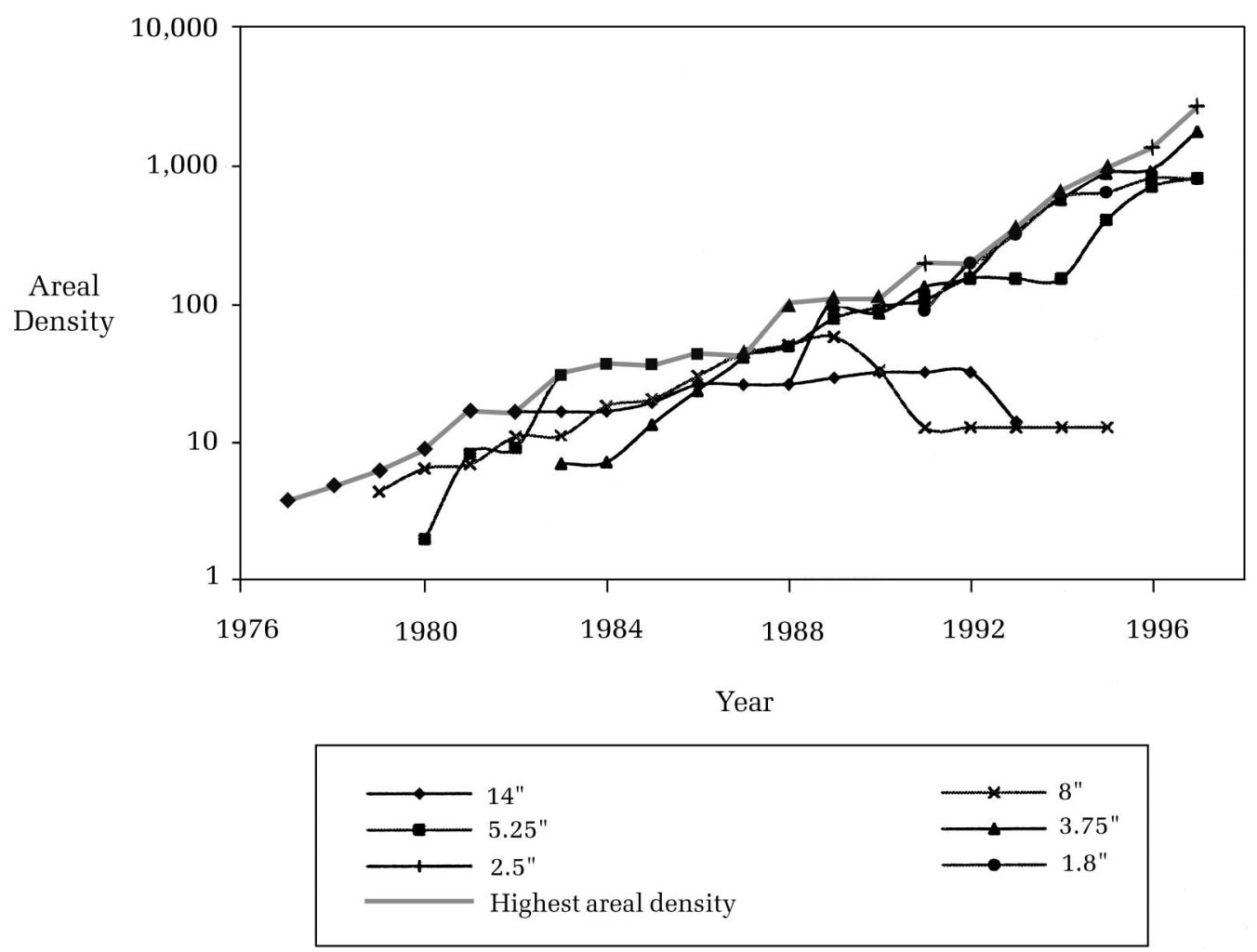

${ }^{\text {a }}$ Megabytes per square inch.

level employees of the parent firms with several years of industry experience. Seventy-two percent of the founders were either research engineers or in production operations, with the rest either in marketing or finance. Further, each spin-out had at least one founder who had engineering or operational experience.

Incumbent-backed entrants, the second entrant group, were affiliated with incumbent firms in the disk-drive industry and included subsidiaries, parent-sponsored ventures, and joint ventures. Diversifying entrants, the third entrant group, were firms that existed in some other industry prior to entering the disk drive industry. The final group, which was our control group, consisted of non-spin-out de novo entrants. These firms were ascertained to have no direct connection to the industry and were not diversifying entrants.

\section{Construct Measurement}

Spin-out generation. This dummy variable took the value of 1 if a spin-out was created in the year following a given year by an employee or employees of a firm founding a new venture, and 0 other- wise. It served as the dependent variable for testing Hypothesis 1.

Technological know-how. We measured a firm's technological know-how in terms of areal density using the following two-step procedure. We first divided the areal density $(A)$ of the best drive produced by firm $i$ of diameter $j$ in year $t$ by the highest areal density in that diameter available in the market that year to obtain the firm's diameter-specific relative technological position $\left(\mathrm{TK}_{\mathrm{ijt}}\right)$ :

$$
T K_{i j t}=\frac{A_{i j t}}{\max \left(A_{i j t}\right)} .
$$

We then averaged the results on this measure across all diameters ( $j=1$ to $\mathrm{n}$ ) produced by the firm in a year to obtain the firm's average relative technological know-how $\left(\mathrm{TK}_{i t}\right)$ in that year:

$$
T K_{i t}=\frac{\sum_{j} T K_{i j t}}{\sum j} .
$$

Measuring a firm's technological capabilities in comparison with the best drive in the market circumvented problems related to cumulative and absolute increases in technological know-how over 
time, since it was a relative time-varying measure that reflected a firm's competitive positioning on technology. We focused on average relative technological know-how across all drives, rather than the relative position of a firm as represented by its best drive, because a firm typically competed in more than one diameter with the other firms in the market, and we were interested in capturing its technological know-how across its product lines. Thus, a firm at the frontier in all the diameters it produced would have a value for technological knowhow equal to 1 , and a firm that was behind the frontier in any one diameter would score less than 1. Our measure was conservative in that firms that produced only older diameters would benefit from other firms dropping these older diameters, while firms that produced a wider range of diameters would tend to score lower on their technological know-how because of higher competition in the newer diameters. This variable served as an explanatory variable for tests of Hypotheses 1 and 4 and as a dependent variable for Hypotheses 2 and 3. Further, technological know-how of the parent in the year preceding a spin-out's entry into the industry was an explanatory variable for Hypothesis 2.

Market pioneering know-how. The five new diameter introductions created new submarkets, and we used these architectural innovations as the basis of our market pioneering know-how measure. The market pioneering know-how variable captured the know-how associated with bringing an innovation to market. Doing so requires undertaking new market orientation strategies, such as scouting opportunities, assessing uncertainty, and ramping up for production. Even though only one firm can be considered the true pioneer for a given product on the basis of order of entry (Golder \& Tellis, 1993), more than one firm may simultaneously engage in market pioneering activities and experience similar time lines. Since our focus was identifying market pioneering know-how, not just a single market pioneer, we included all firms that entered in the first year of a market segment's introduction in our measurement. Robustness checks indicated that the results did not change when order of entry rather than year of entry was used as the criterion for firm inclusion. Our measure recognized the multiple market pioneering opportunities represented by the creation of submarkets, as opposed to only the opportunity of introducing the first submarket (that is, the 14-inch-diameter drive). As a result, our measure varied over time and across firms. We measured market pioneering know-how as the number of times a firm introduced drives of new diameters within the first year of their introduction into the industry divided by the total number of new diam- eter introductions in the industry since the firm's year of entry. Mathematically,

$$
\begin{aligned}
M P K_{i t}= & \frac{\sum_{k=E_{i}}^{t} P_{i k}}{\sum_{k=E_{i}}^{t} D_{k}} \text { if } \sum_{k=E_{i}}^{t} D_{k}>0 . \\
=0, & \text { if } \sum_{k=E_{i}}^{t} D_{k}=0
\end{aligned}
$$

where $E_{i}$ is the year of entry of the $i$ th firm, $t$ is the current year of operation, $P_{i k}$ is a dummy variable that indicates whether the firm was an early mover when a new diameter was introduced $\left(P_{i k}=1\right.$ if a firm introduced a drive of a new diameter within the first year of the diameter's introduction into the industry and 0 otherwise), and $D_{k}$ is a dummy variable that indicates whether there was a diameter introduction during that year $\left(D_{k}=1\right.$ if a diameter was introduced and 0 otherwise). For each firm operating in the market at the time of a new diameter's introduction, the denominator of the variable increased by 1 , and the numerator increased by 1 only if the firm was an early mover for that diameter. ${ }^{3}$ For firms that entered between two consecutive diameter introductions, the market pioneering know-how variable took the value of 0 until the year of the next diameter introduction. Treating the variable as missing for these firm-years did not change the results. In keeping with most of the work on first-mover advantages, we assumed no depreciation of market pioneering know-how. ${ }^{4}$

\footnotetext{
${ }^{3}$ For example, consider a hypothetical firm $\mathrm{X}$ that entered the industry in 1979 producing an 8-inch drive, started production of the 5.25-inch drive in 1981 and of the 3.75-inch drive in 1983, and exited in 1987. Since 1979 was the first year that the 8-inch drive was produced, and firm $\mathrm{X}$ was an early mover in that diameter, its market pioneering know-how variable value in 1979 is 1. In 1980, the first year in which the 5.25-inch drive was produced, the firm did not enter the submarket. Thus, the variable value for firm $\mathrm{X}$ is updated to become 0.5 . This value remains unchanged until 1983, the year of the next diameter's introduction. Since firm X was an early mover in the 3.75-inch drive, the variable value is updated to 0.67 and remains unchanged until the firm exits in 1987, as the next diameter introduction occurred in 1988.

${ }^{4}$ Although this measurement was the most intuitively appealing, we experimented with alternative measures that included the absolute number of times a firm could be considered an early mover, the negative of the number and proportion of missed pioneering opportunities (the
} 
This variable served as an explanatory variable for testing Hypotheses 1 and 4 and as a dependent variable for Hypotheses 2 and 3. Further, the market pioneering know-how of a parent in the year preceding a spin-out's entry into the industry was an explanatory variable for Hypothesis 2 .

Entrant survival. The dependent variable for $\mathrm{Hy}-$ pothesis 4 was computed as a dummy variable with a value of 1 if a firm survived to the year following an observation (with acquisitions being treated as censored observations) and a value of 0 otherwise.

Spin-out. This explanatory variable for Hypotheses 3 and 4 was coded 1 if at least one founder of a firm was an ex-employee of an incumbent firm in the year prior to its formation and 0 otherwise.

Incumbent-backed entrant. This explanatory variable for Hypotheses 3 and 4 was coded 1 if a firm was affiliated (was a subsidiary or joint venture, or parent-backed) with an incumbent in the disk drive industry and 0 otherwise.

Diversifying entrant. This explanatory variable for Hypotheses 3 and 4 was coded 1 if a firm existed in some other industry prior to entering the disk drive industry and 0 otherwise.

Control variables. Firm-level control variables included measures for sales, growth, age, and country of origin. The logged value of all annual disk drive sales in millions of dollars, measured firm sales, and firm growth was the percent change in sales over successive years. Firm age was the number of years since entry into the disk drive industry, and we used a quadratic term to incorporate potential nonlinear effects of age. Since foreign firms may differ from U.S. firms for institutional reasons, we used a dummy variable, foreign entrant, coded 1 for non-U.S. origin and 0 otherwise. Note that since only one foreign firm generated a spin-out, this variable was not included in testing Hypotheses 1 and 2, which pertain to spin-out formation/ inheritance from parents. Further, to control for the potentially negative effect on a spin-out's performance of parent presence in the same market segment, we included a dummy variable coded 1 if a parent was present in the diameter in which the spin-out first entered and 0 otherwise. Similarly, we included firm diversity, measured as the difference between the number of diameters produced by a firm and the average number of diameters produced by all firms in a given year to control for the

number of times that the firm did not pioneer a diameter, divided by the number of new diameter introductions since year of firm entry), and an ordinal rank measure of market pioneering. All these variables yielded similar substantive results. effects of diversity and scope of operations relative to the mean diversity and scope of operations in the industry. Finally, to control for any systematic effect of entry prior to the period under investigation, we included firm incumbent in 1976, coded 1 if a firm had entered the industry prior to 1977.

Industry-level controls included a measure of the technological frontier in a particular year, the highest areal density in industry (information per square inch) of a drive across all the diameters produced in a given year. Additional industry control variables were annual industry sales and industry growth, measured in a similar manner as firm sales and growth, number of firms, and number of entrants. These variables controlled for important industry evolution and competitive density effects (Brittain \& Freeman, 1980). Finally, year dummies for the entry year of a firm were included to control for differences in founding conditions.

\section{Estimation}

Hypothesis 1 relates to the probability of a firm's generating a spin-out in a given year. We used all firm-year observations in the sample, since every firm was a potential parent in any given year. Of the several models available for analyzing such phenomena, we chose a hazard rate methodology to account for the fact that each firm was represented more than once in a data structure that included firm-year as a unit of observation. Since our Hypothesis 1 dependent variable could also be measured as a count of spin-outs generated, we also tested the hypotheses using random-effects Poisson and negative binomial models, and the results were robust to these alternative model specifications. Several discrete and continuous time models were available for the estimation of hazard rates (Allison, 1995); following earlier studies (Henderson, 1999), we used a multiple-spells formulation with a complementary log-log specification. Since a firm could generate a spin-out at any point within a given year but the data on spin-out generation were updated only annually, a multiple-spells formulation allowed us to recover continuous-time hazard rates from discrete-time data. Also, such a specification allowed easier incorporation of time-varying covariates. Our results were robust to alternative hazard rate estimation techniques, including Cox proportional hazard and piecewise exponential models.

Hypothesis 2, pertaining to spin-outs' knowledge, was tested by restricting the sample to firmyear observations for spin-outs only. Since our operational definition of a spin-out required founding 
within one year of the founder leaving the parent organization, we were able to use the parent's technological and market pioneering know-how in the year prior to the spin-out's entry in the hypotheses testing the inheritance of knowledge. The chief independent variables of interest-parent technological and market pioneering know-how-were timeinvariant, and the analyses tested their effect on the spin-out's technological know-how and market pioneering know-how over the spin-out's life span to check for long-term effects. To control for the effect of time, we included both entry-year dummies and spin-out age in the model. We tested the Hypothesis 3 prediction of differences between spin-out and non-spin-out entrants' know-how by including the firm-year observations of all entering firms. This restriction caused us to exclude firms that entered prior to 1976 for these models. For both Hypotheses 2 and 3, we used seemingly unrelated regression models (SUR) to account for potential correlations of the errors across the technological and market pioneering know-how equations. Owing to the complexity of the error variance-covariance matrix when both cross-equation and autocorrelation constraints are introduced, existing commercial software packages do not accommodate panel-based SUR models, the ideal model given the nature of our data. In the absence of such methods, we tested the hypotheses using both random-effects panel regression and SUR models separately, and the results were largely similar. We report the SUR results, which we believe are more appropriate since SUR allows for (1) separate variances and (2) contemporaneous correlation of the error terms of each equation, in contrast to panel models that assume homogeneous distribution of the error terms for various cross-sections, thus leading to more efficient estimates (Mckenzie \& Thompson, 1997). Finally, to test for differences between spin-out and non-spin-out entrant survival (Hypothesis 4), we restricted the sample to all entrants again, and used hazard rate methodology for the analysis of survival probabilities. As before, we estimated additional model specifications to ensure robustness and found the results to be substantively similar across different models.

\section{RESULTS}

Descriptive statistics and correlations on the variables included in the analysis are presented in Table 1. An examination of the bivariate correlations in Table 1 reveals that multicollinearity was not a major issue. We computed variance inflation factors and found no evidence of severe collinearity. Since the term for the interaction between tech- nological know-how and market pioneering knowhow was constructed by multiplying the two "main effects," there was a possibility that multicollinearity might confound the test of the simple effects by inflating the standard errors. Our analysis revealed that the effects of market pioneering know-how and technological know-how were significant in the presence of the interaction and that the standard errors were reasonable. Also, a comparison of the coefficients of models 1 and 2 in Table 2 revealed that all coefficients were stable across the two models.

We now turn to the testing of our hypotheses. Hypothesis 1 relates incumbent firm know-how to spin-out generation. Accordingly, the observations pertained to a firm's being a potential parent in every single year after its entry, or after 1976 for firms that entered prior to this date. The results of the test of Hypothesis 1 are shown in Table 2. In model 1, the main effects of technological knowhow and market pioneering know-how on spin-out generation, along with control variables, were entered. In model 2, we entered and estimated the multiplicative interaction of the two know-how variables.

Results from both models show that the probability of generating a spin-out in a following period was positively related to the main effects of technological know-how and market pioneering knowhow of an incumbent in the previous year. Model 2 shows that the interaction between the two types of know-how had a negative impact on the probability of generating a spin-out. Taken together, models 1 and 2 imply that while increases in either technological or market pioneering know-how increased the likelihood of generating spin-outs, increases in both know-how dimensions were less likely to generate spin-outs, thereby supporting Hypothesis $1 .^{5}$

Table 3 presents test results for Hypothesis 2, which relates a spin-out's know-how levels over its lifetime to the know-how levels of the parent firm in the year prior to the spin-out's formation. Using firm-year observations pertaining to the spin-outs, models 1 (technological know-how) and 2 (market pioneering know-how) report results related to the impact of parents' know-how on the know-how of

\footnotetext{
${ }^{5}$ We also conducted additional analysis using the absolute difference between technological and market pioneering know-how. The coefficient of this term was positive and significant, indicating that the higher the gap between technological and market pioneering knowhow, the greater the likelihood of spin-out generation. This finding provided additional support for Hypothesis 1 , since firms that had higher values of either technological or market pioneering know-how, but not both, were more likely to generate spin-outs.
} 
TABLE 1

Descriptive Statistics $^{a}$

\begin{tabular}{|c|c|c|c|c|c|c|c|c|c|c|c|c|c|c|c|c|c|c|c|c|c|c|}
\hline Variable & Mean & s.d. & 1 & 2 & 3 & 4 & 5 & 6 & 7 & 8 & 9 & 10 & 11 & 12 & 13 & 14 & 15 & 16 & 17 & 18 & 19 & 20 \\
\hline 1. Spin-out generation & 0.04 & 0.21 & & & & & & & & & & & & & & & & & & & & \\
\hline 2. Firm survival & 0.88 & 0.33 & -.01 & & & & & & & & & & & & & & & & & & & \\
\hline 3. Technological know-how & 0.44 & 0.23 & .03 & .09 & & & & & & & & & & & & & & & & & & \\
\hline 4. Market pioneering know-how & 0.07 & 0.22 & .14 & -.01 & .11 & & & & & & & & & & & & & & & & & \\
\hline 5. Parent technological know-how & 0.10 & 0.25 & .07 & .03 & .22 & .11 & & & & & & & & & & & & & & & & \\
\hline $\begin{array}{l}\text { 6. Parent market pioneering know- } \\
\text { how }\end{array}$ & 0.32 & 0.46 & -.02 & .06 & -.13 & .07 & .11 & & & & & & & & & & & & & & & \\
\hline 7. Spin-out & 0.30 & 0.46 & .18 & .06 & .29 & .29 & .62 & .06 & & & & & & & & & & & & & & \\
\hline 8. Incumbent-backed firm & 0.03 & 0.18 & -.03 & -.06 & .03 & -.06 & -.08 & -.06 & -.12 & & & & & & & & & & & & & \\
\hline 9. Diversifying firm & 0.18 & 0.38 & -.04 & .04 & .03 & -.03 & -.20 & .03 & -.29 & -.01 & & & & & & & & & & & & \\
\hline 10. Foreign firm & 0.23 & 0.42 & -.09 & -.05 & -.23 & -.09 & -.20 & -.09 & -.36 & -.10 & -.14 & & & & & & & & & & & \\
\hline 11. Firm incumbent in 1976 & 0.31 & 0.46 & .02 & .08 & .09 & -.07 & -.28 & -.24 & -.28 & .00 & .47 & -.37 & & & & & & & & & & \\
\hline 12. Firm age & 6.19 & 5.84 & -.02 & .01 & .21 & .12 & -.15 & -.13 & -.11 & -.08 & .45 & -.21 & .47 & & & & & & & & & \\
\hline 13. Parent presence & 0.08 & 0.27 & .03 & .05 & .14 & .00 & .49 & -.12 & .45 & -.05 & -.14 & -.16 & -.20 & -.06 & & & & & & & & \\
\hline 14. Firm diversity & -0.01 & 0.97 & .01 & .13 & .16 & .10 & -.09 & -.06 & -.06 & -.06 & .47 & -.24 & .43 & .51 & -.01 & & & & & & & \\
\hline 15. Firm sales & 4.28 & 12.75 & .06 & .41 & .09 & .11 & -.21 & -.15 & -.08 & -.04 & .28 & -.17 & .36 & .38 & -.08 & .47 & & & & & & \\
\hline 16. Firm growth & 0.21 & 0.65 & .06 & .28 & -.01 & .09 & .07 & .12 & .10 & .00 & -.10 & .10 & -.19 & -.24 & .07 & -.02 & .36 & & & & & \\
\hline 17. Industry sales & 16.33 & 0.67 & -.09 & -.14 & .04 & .01 & .11 & .09 & .05 & -.04 & .09 & .28 & -.32 & .35 & .05 & .00 & -.01 & -.19 & & & & \\
\hline 18. Industry growth & 0.14 & 0.10 & .04 & .07 & -.10 & .05 & -.03 & -.03 & .01 & .04 & .03 & -.14 & .14 & -.24 & .00 & .00 & .00 & .17 & -.55 & & & \\
\hline $\begin{array}{l}\text { 19. Highest areal density in } \\
\text { industry }\end{array}$ & 195.37 & 437.56 & -.06 & .02 & .09 & -.01 & .03 & .03 & .01 & -.05 & -.02 & .07 & -.10 & .31 & -.02 & .00 & .06 & -.09 & .48 & -.31 & & \\
\hline 20. Number of firms in industry & 62.70 & 16.93 & .05 & .02 & -.11 & .09 & .02 & .02 & .05 & .06 & .09 & -.07 & .03 & -.24 & .05 & .00 & -.03 & .14 & -.17 & .58 & -.68 & \\
\hline 21. Number of entries & 7.97 & 4.48 & .10 & .05 & -.08 & .09 & -.01 & .00 & .03 & .03 & .02 & -.14 & .10 & -.24 & .01 & .00 & -.05 & .12 & -.45 & .52 & -.57 & .72 \\
\hline
\end{tabular}

${ }^{\mathrm{a}} n=1,180$. All correlations above $|.06|$ are significant at the .05 level. 
TABLE 2

Results of Hazard Rate Analysis for Firm Knowhow and Spin-out Generation ${ }^{a}$

\begin{tabular}{|c|c|c|}
\hline Variables & Model 1 & Model 2 \\
\hline Intercept & $-35.80 \quad(24.05)$ & $-41.46 \quad(24.87)$ \\
\hline Technological know-how & $2.49 *(0.86)$ & $3.72 *(1.06)$ \\
\hline $\begin{array}{l}\text { Market pioneering know- } \\
\text { how }\end{array}$ & $1.59 *(0.54)$ & $3.59 *(1.10)$ \\
\hline $\begin{array}{l}\text { Technological know-how } \times \\
\text { market pioneering know- } \\
\text { how }\end{array}$ & & $-3.84^{+}(1.94)$ \\
\hline Firm age & $-0.16 \quad(0.18)$ & $-0.18 \quad(0.18)$ \\
\hline Firm age squared ${ }^{\mathrm{b}}$ & $0.02 \quad(0.10)$ & $0.03 \quad(0.10)$ \\
\hline Firm sales & $0.51 *(0.16)$ & $0.47 *(0.16)$ \\
\hline Industry sales & $0.57 \quad(1.47)$ & $0.67 \quad(1.50)$ \\
\hline Firm growth & $0.15 \quad(0.39)$ & $0.20 \quad(0.39)$ \\
\hline Industry growth & $-2.73(2.82)$ & $-2.52 \quad(2.78)$ \\
\hline $\begin{array}{l}\text { Highest areal density in } \\
\text { industry }\end{array}$ & $-0.12 \quad(0.02)$ & $-0.02 \quad(0.02)$ \\
\hline Firm product diversity & $-0.53^{+}(0.29)$ & $-0.60^{+}(0.28)$ \\
\hline Firm incumbent in 1976 & $-0.59 \quad(0.73)$ & $-0.49 \quad(0.75)$ \\
\hline $\begin{array}{l}\text { Number of firms in } \\
\text { industry }\end{array}$ & $0.84^{+}(0.36)$ & $0.95 *(0.38)$ \\
\hline $\begin{array}{l}\text { Number of firms in } \\
\text { industry squared }\end{array}$ & $-0.01 *(0.00)$ & $-0.01^{*}(0.00)$ \\
\hline Number of entrants & $-0.03 \quad(0.08)$ & $-0.02 \quad(0.08)$ \\
\hline$\chi^{2}$ & $53.46^{*}$ & $57.48^{*}$ \\
\hline Log-likelihood & -85.98 & -83.97 \\
\hline
\end{tabular}

\footnotetext{
${ }^{\text {a }} n=1,180$. Standard errors are in parentheses.

b $\times 10^{-1}$

${ }^{+} p<.10$

${ }^{*} p<.05$
}

their spin-outs. Results show that the parent's technological and market pioneering know-how measured in the year preceding spin-out entry are strongly significant in predicting a spin-out's technological and market pioneering know-how, respectively, thereby supporting Hypothesis 2.

Table 4 reports the results for Hypothesis 3 using all firm-year observations for the post-1977 entrants into the industry. Models 1 and 2 report the variation among the three types of entrants-spinouts, incumbent-backed entrants, and diversifying entrants-on technological and market pioneering know-how, respectively. Non-spin-out de novo entrants were the control group. The results for model 1 show that both spin-outs and incumbent-backed entrants had higher technological know-how than the control group. The coefficient of diversifying entrants was negative and significant, indicating that the technological know-how of diversifying entrants was lower than the control group's. Model 2 reveals that spin-outs had higher levels of market pioneering know-how than the control group. The coefficient of incumbent-backed entrants was not significant, but the coefficient of diversifying entrants was once again negative and significant. Together, these results indicate that spin-out firms have higher know-how levels than both diversifying entrants and non-spin-out de novo entrants, thereby supporting Hypothesis $3 .^{6}$

Table 5 reports the results from the hazard rate analysis. It shows that spin-outs had a higher probability of survival than all other types of entrants, thereby supporting Hypothesis 4. ${ }^{7}$ Higher technological know-how also increased the probability of survival, but market pioneering know-how did not appear to affect the probability of survival.

\section{DISCUSSION}

Research suggests that the origins of new firms may explain heterogeneity in their capabilities and performance. Explanations of where new entrants come from and how they acquire their initial stocks of knowledge are thus issues central to organization scholars. In this context, although it has been noted that preentry experience and founders' prior employment affiliations fashion a de novo's resources and capabilities, scholars' theoretical and empirical understanding is limited. The gap is especially pronounced for spin-outs, or entrepreneurial ventures founded by former employees of incumbent firms. Spin-outs, which are a particularly innovative and powerful form of new entrant, have been eulogized as "paragons of innovation" as well as criticized for being "rapacious plunderers" of their parent's innovations (Klepper, 2001). However, despite anecdotal evidence and some preliminary research, there seems to have been little scientific investigation of their formation, knowledge inheritance, and performance. In this research, we adopted a knowledge perspective and studied how the technological and market pioneering knowhow of an incumbent influenced spin-out formation (Hypothesis 1), how parental know-how at the time of spin-out formation affected spin-out knowledge level (Hypothesis 2), and whether spin-outs differed from other entrants in their knowledge levels (Hypothesis 3) and survival chances (Hypothesis 4$)$.

\footnotetext{
${ }^{6}$ There were 40 spin-outs based on our definition, but 6 additional firms were started by former employees more than one year after leaving incumbent firms. The results were robust to tests that included these firms.

${ }^{7}$ As before, the results were robust to sensitivity tests for inclusion of firms founded by employees more than a year after leaving incumbents.
} 
TABLE 3

Results of Seemingly Unrelated Regression Analysis for Inheritance of Knowledge ${ }^{\mathrm{a}}$

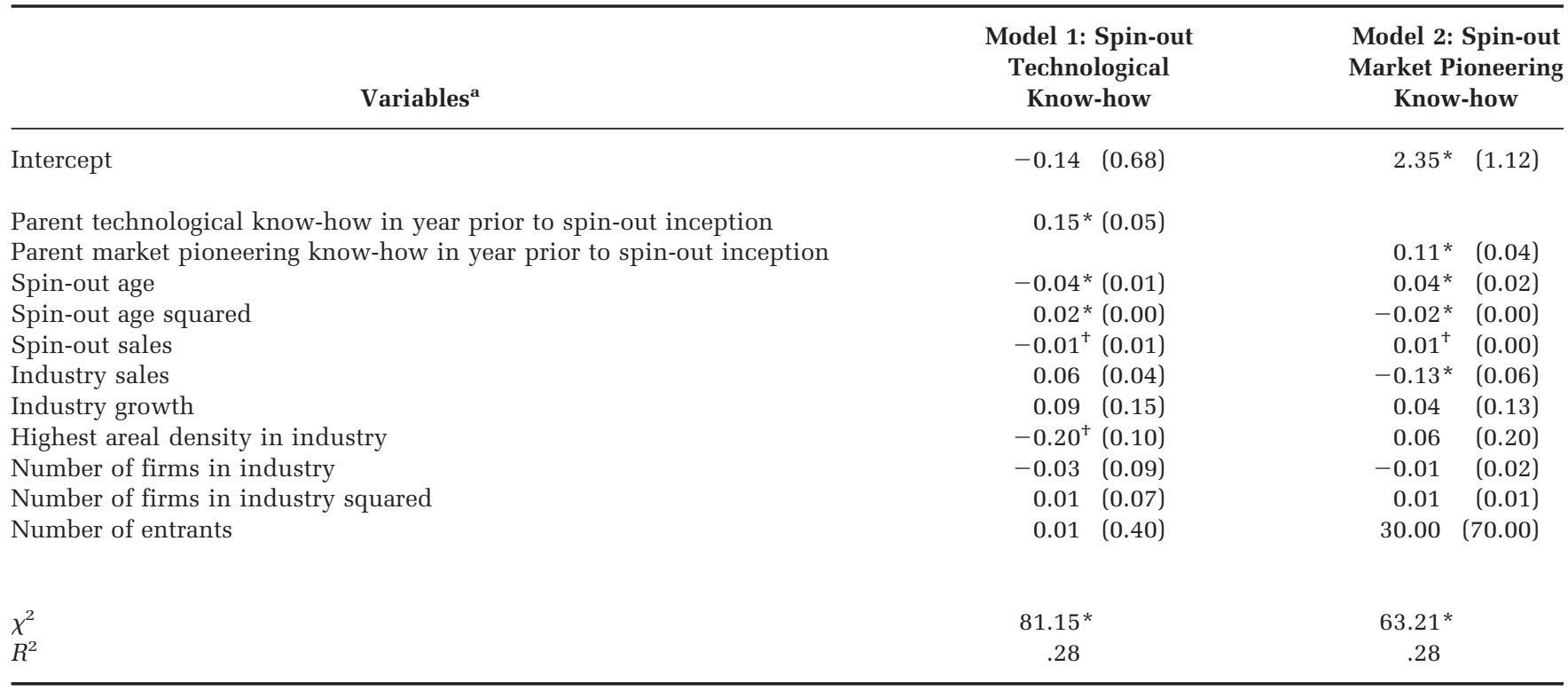

${ }^{\mathrm{a}} n=344$. Standard errors are in parentheses. Year-of-entry dummies were included but are not reported. For spin-out age squared, spin-out sales, and number of firms in industry, $\times 10^{-1}$; for highest areal density, $\times 10^{-3}$; for number of firms in industry squared, $\times 10^{-2}$; and for number of entrants, $\times 10^{-4}$.

${ }^{+} p<.10$
${ }^{*} p<.05$

TABLE 4

Results of Seemingly Unrelated Regression Analysis for Technological and Market Pioneering Know-how of Entrants ${ }^{a}$

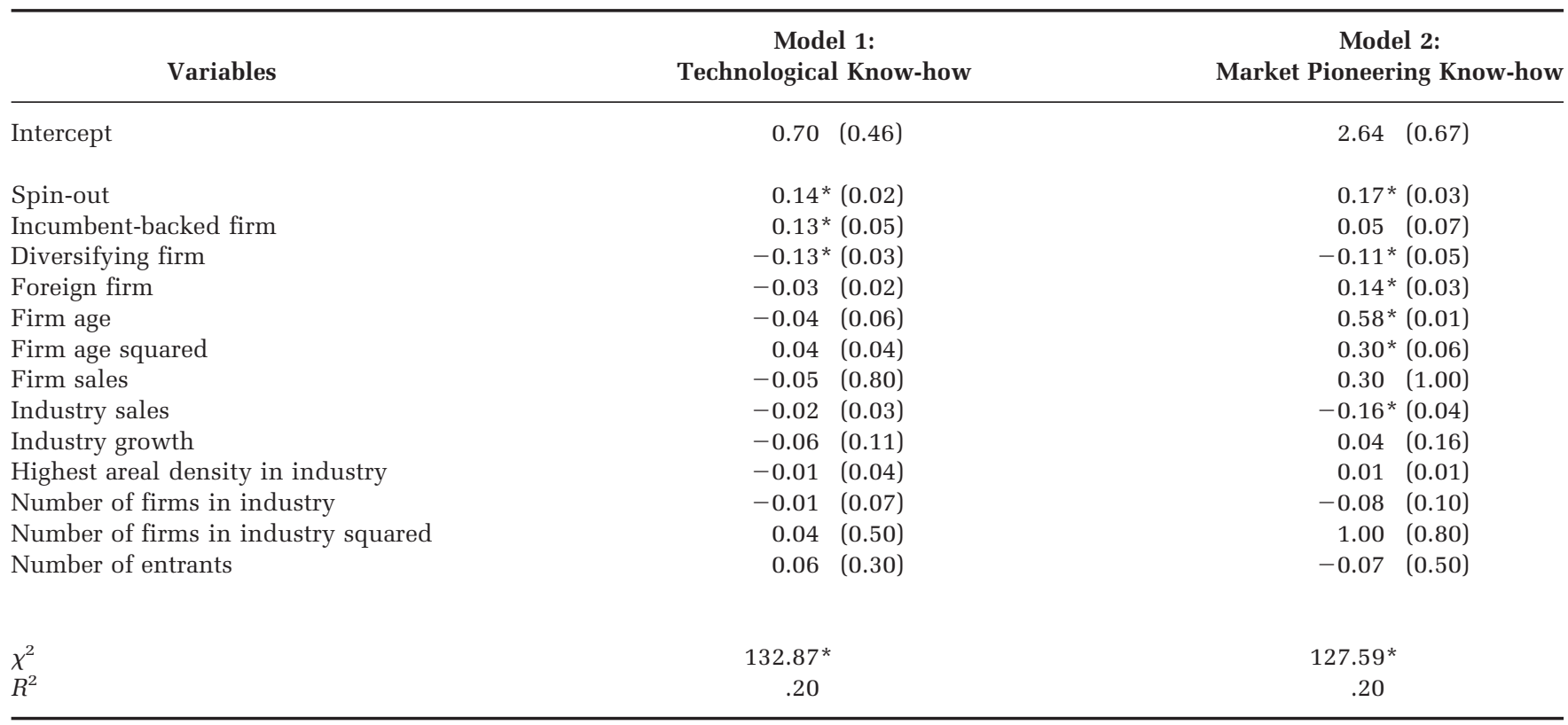

${ }^{\mathrm{a}} n=767$. Standard errors are in parentheses. Year-of-entry dummies were included but are not reported. For firm age and number of firms in industry, $\times 10^{-1}$; for firm age squared, firm sales, and number of entrants, $\times 10^{-2}$; for highest areal density, $\times 10^{-3}$; and for number of firms in industry squared, $\times 10^{-4}$.

${ }^{*} p<.05$ 
TABLE 5

Probability of Survival of Entrants ${ }^{a}$

\begin{tabular}{lc}
\hline \multicolumn{1}{c}{ Variable } & Model \\
\hline Intercept & $28.63^{*}(12.95)$ \\
& \\
Spin-out & $0.70^{*}(0.31)$ \\
Incumbent-backed firm & $-0.67(0.52)$ \\
Diversifying firm & $-0.10(0.43)$ \\
Technological know-how & $0.84^{*}(0.42)$ \\
Market pioneering know-how & $-0.20(0.35)$ \\
Foreign firm & $0.40(0.28)$ \\
Firm age & $-0.11(0.16)$ \\
Firm age squared & $0.01^{+}(0.01)$ \\
Firm sales & $0.05^{*}(0.01)$ \\
Parent presence in diameter of entry & $0.72(0.48)$ \\
Highest areal density in industry & $0.03^{*}(0.01)$ \\
Industry sales & $-2.34^{*}(0.89)$ \\
Industry growth & $-0.89(1.47)$ \\
Number of firms in industry & $0.32^{*}(0.09)$ \\
Number of firms in industry squared & $-0.02^{*}(0.01)$ \\
Number of entrants & $-0.05(0.04)$
\end{tabular}

Log-likelihood

$-261.43$

${ }^{a} n=767$. Standard errors are in parentheses. Year-of-entry dummies were included but are not reported. Highest areal density and number of firms in industry squared, $\times 10^{-1}$.

${ }^{+} p<.10$

${ }^{*} p<.05$

With respect to the hypothesis on spin-out generation, the results of this research suggest that organizations with abundant, but underexploited, knowledge are especially fertile grounds for spinout formation. An imbalance in an organization's focus on value creation and value appropriation increases its likelihood of generating spin-outs. Anecdotal evidence from Christensen (1997) showed that Conner Peripherals was founded by disaffected employees of Seagate and Miniscribe, the two largest 5.25-inch disc drive manufacturers, who had developed the 3.5-inch drive but had decided against marketing it. Similarly, the founders of Micropolis, an early mover in production of the 8-inch drive, came from Pertec, a 14-inch drive manufacturer. Incumbent firms, however, appear to have retained their employees by proactively investing in both technological and market pioneering knowhow. For example, Quantum and Control Data created subsidiaries that targeted emerging segments to prevent spin-out formation. Another case in point is Micropolis, itself a spin-out and an early mover, which successfully made the transition to a new platform by managing the change from within the existing organization, and succeeding in retaining its employees. This evidence supports the idea that it is not abundance of knowledge per se, but its utilization, that determines spin-out generation. An implication is that rather than resigning themselves to the notion that knowledge is a double-edged sword that results in competition from within, managers can orient their strategies toward simultaneous value creation and appropriation, and thus limit competition. Our findings also indicate that though size is positively associated with spin-out formation, a potential parent's presence in a large number of market segments lowers chances of spinout formation. The nonsignificant effect of age indicates that spin-out generation was not related to firm age.

In support of the notion that knowledge may be inherited, we found that parental knowledge levels at the time of spin-out formation positively affected spin-outs' knowledge levels. For instance, all but one of the new diameters were introduced by spinouts, even though the technology had been developed by an incumbent. Also, progenies of parents with high knowledge levels appear to have higher knowledge levels, not only with respect to the progenies of parents with lower knowledge levels, but also with respect to their own parents. Only 4 of the 40 spin-outs had lower technical know-how measures than their parents at the time of inception. Thirty-three percent of spin-outs whose parents were market pioneers were market pioneers themselves, while non-market-pioneering parents resulted in only 6.8 percent of spin-outs that were market pioneers. Further, our results support the notion that direct links to industry knowledge through founders better facilitates the integration of this knowledge than grafting knowledge through hiring employees with industry experience. Given that incumbent-backed ventures have similar direct access to knowledge, we did not formally hypothesize any advantage in knowledge capabilities for spin-outs with respect to this group. The results are mixed on the two dimensions of knowledge capabilities. Although incumbent-backed ventures, like spin-outs, have higher levels of technological know-how, they do not have similarly higher levels of market pioneering know-how. In terms of a key performance dimension, we found that spin-outs survived at a higher rate than any other form for entrant into the industry, thus supporting our notion that their entrepreneurial form and origin from incumbents endow spin-outs with greater motivation and capabilities. It is interesting to note, in this context, the inability of incumbent-backed ventures to either gain market pioneering know-how, or more importantly, have better survival chances. These findings seem to indicate that incumbentbacked ventures may be subject to certain disadvantages stemming from initial or continued paren- 
tal involvement. This suggestion further highlights the importance of entrepreneurial flexibility. Finally, while not a hypothesized relationship, the insignificance of market pioneering in explaining survival suggests that by itself, pioneering may not sustain longevity. This notion is consistent with the research on first and early mover advantages, which has indicated that although early entrants may have higher returns (that is, market share), they may not necessarily experience higher survival rates than later followers because of the greater technological and market uncertainty that characterize new markets (e.g., Lieberman \& Montgomery, 1998; Mitchell, 1991; Shepherd, 1999).

\section{Theoretical Contributions}

As Klepper (2001) noted, theorizing on high-tech spin-outs is in its infancy. This study used a knowledge-based approach to integrate ideas on knowhow inheritance and employee entrepreneurship to construct theory on spin-out formation and development. In the process of enhancing understanding of these entrepreneurial change agents, we advance the knowledge-based view of the firm. Although extant work has indicated that spin-outs may be triggered by organizational crisis, change in leadership, or lack of upward mobility for employees (Brittain \& Freeman, 1986; Garvin, 1983), fundamentally researchers know little about why some incumbents tend to become "entrepreneurial hotbeds" (Burton et al., 2002). By providing evidence of the systematic links between human capital, knowledge-based capabilities, and spin-out formation, our research redirects attention to the knowledge-based view of the firm as a potentially fruitful theoretical lens through which to study this very important phenomenon. We have also addressed an important dichotomy in the knowledge-based view of the firm between exploratory, knowledgegenerating activities that increase the stock of knowledge, and exploitation activities concerned with knowledge application (Spender, 1992). Reconciling the dichotomy between knowledgecreating and knowledge-applying activities represents a key challenge of considerable difficulty for the institutions of production (Grant, 1996). Such complex interdependencies between different types of knowledge have been noted, but our study went further by modeling and finding potentially adverse consequences of knowledge when organizations fail to resolve this duality. Emphasis on only one domain of knowledge results in pockets of underexploited knowledge, which leads to knowledge spillovers through employee entrepreneurship. This means not only a failure to appropriate the full value of R\&D and business process investments for a firm, but also an undesirable increase in competition.

Second, we contribute to the ongoing debate surrounding the identity of the fields of entrepreneurship and strategic management. ${ }^{8}$ Scholars have argued that the distinction lies in entrepreneurship's focus on value creation and strategic management's emphasis on value appropriation (Shane \& Venkataraman, 2000; Zahra \& Dess, 2001). Integrating these two views of wealth creation, Hitt, Ireland, Camp, and Sexton (2001) advanced the notion of "strategic entrepreneurship." Our arguments and subsequent finding that firms need to accomplish a syncretic balance between value creation and appropriation supports this general idea. Thus, an important implication of our study is the need to view strategic entrepreneurship through dual lenses of value creation and appropriation.

Third, although organizational learning scholars have speculated about knowledge inheritance, we provide hard evidence that genealogical knowledge links do exist between parent and progeny organizations. Our study thus may be among the first to empirically substantiate the phenomenon of knowledge inheritance. Further, our finding that knowledge transfers more effectively through founders than through employees indicates that the agent of knowledge transfer is an important determinant of its efficacy.

Fourth, we add to the growing literature on entrepreneurship relating to initial endowments. In addition to social capital, employee entrepreneurs also benefit from the knowledge they acquire while working with incumbent firms. Entrepreneurship theories thus need to address how apprenticeships with leading incumbent firms may impact entrepreneurial capital. Finally, our findings provide evidence of the advantages conferred by the dual presence of entrepreneurial flexibility and preentry experience on new ventures. Existing studies have typically compared diversifying and de novo entrants and argued that incumbency and the ability to transfer and leverage knowledge across various business units of a firm (Teece \& Pisano, 1994) bestows de alio entrants with "dominance by birthright" (Carroll et al., 1996; Klepper \& Simons, 2000). Very few advantages that enable de novo entrants to compete successfully have been identified, other than their flexibility (Tushman \& Anderson, 1986). By distinguishing between four types of entrants and comparing spin-outs with

\footnotetext{
${ }^{8}$ We appreciate the insights provided by an anonymous reviewer on this issue.
} 
other de novo entrants, diversifying entrants, and incumbent-backed entrants (Helfat \& Lieberman, 2002), our findings indicate that spin-out de novo firms benefit not only from the advantage of entrepreneurial origin, but also from inherited knowledge.

\section{Limitations and Future Research}

Our study's limitations also provide exciting areas for future research. First, care should be taken about overgeneralizing the findings from a single industry, and future research could investigate the extent to which our framework holds in other industries. Second, our measure of firm size relied on disk drive sales rather than number of employees. ${ }^{9}$ Previous research has indicated that these alternative measures of firm size are highly correlated and thereby will yield similar results (Chandy \& Tellis, 2000), and tests on our subsample of all publicly traded disk drive firms bore out this fact. However, our use of sales rather than employees is a limitation of our study, given its focus on human capital and entrepreneurial motives. Third, we found that though some firms specialized in advancing either scientific or marketing knowledge, others did both, thus raising issues regarding knowledge development processes and decisions that lead firms on various knowledge paths. Future work may need to explore whether the organization of capabilities may be as important a source of performance heterogeneity as the capabilities themselves. In other words, rather than keeping a singular focus on knowledge quantity, research may benefit by investigating knowledge portfolios (Leiponen, 2003). Fourth, although we established a relationship between parental and progeny knowledge, we were unable to unravel endowment and learning effects and learn whether spin-outs learn faster and better than other entrants, or whether non-spin-out entrants can ever catch up. This question is important given that over time, a firm may lose its technological lead, even though it may have entered with cutting-edge knowledge (Bahk \& Gort, 1993). Moreover, diminishing returns to learning may imply that the higher the stock of know-how, the lower the rate of subsequent learning. Firms with low stocks of know-how may be able to learn quickly if they can build on superior knowledge outside their boundaries, but firms with high stocks of knowledge may make slow progress if they face the

\footnotetext{
${ }^{9}$ Including employee data, which were not available for the smaller or private firms, would have restricted the sample to the larger, public firms, causing problems of selection bias.
}

harder task of creating new knowledge as the basis of their learning. These confounding effects make it difficult to make assertions about the effects of the presence (or absence) of learning.

Fifth, our data precluded a finer-grained analysis of founders. There are exciting questions related to founder characteristics, and founders' specific experiences as employees, that may shape the new ventures they form. Even though all the founders of the spin-outs in the sample had held high positions in research, manufacturing, or marketing at the incumbent firms, they otherwise varied. Future research needs to address how variations in expertise, hierarchical position, and management team characteristics influence the effectiveness of knowledge transfer and whether there are network effects at play in the formation of founder teams. Despite our ensuring that there were no formal ties between parents and progeny, we could not ascertain the absence or presence of informal ties. Sixth, data limitations necessitated pooling several different forms of incumbent-backed entrants. Therefore, care must be taken in the interpretation of the results related to incumbent-backed ventures. It would be particularly important for future research to identify incumbent-backed ventures created to encourage "intrapreneurship" and deter spin-out formation and gauge their performance consequences. Finally, although the assumption in survival studies is that survival and good economic performance are equivalent, there is evidence that, due to varying performance thresholds, some underperforming firms persist, whereas proactive exit can occur without economic dissolution (Gimeno, Folta, Cooper, \& Woo, 1997). Our study therefore suffers from a limitation that is endemic to most survival studies. Future research needs to investigate variables such as market share and financial performance.

\section{CONCLUSION}

Our research addresses an important phenomenon-the rise of the spin-out as a particular type of entrepreneurial entrant in high-technology, innovation-oriented industries. The broad research questions in our work set foundations for a research agenda on spin-outs. Our findings regarding formation suggest that it is not merely abundant incumbent knowledge per se, but its utilization, that has implications for spin-out generation, thus suggesting that firms need to strategically invest their resources in simultaneous value creation and appropriation capabilities, rather than specialize to the detriment of a complementary capability. From a spin-out perspective, it appears that knowledge cor- 
ridors prior to formation are critical. Knowledge is in fact inherited, and a firm's founder is a potentially more effective agent of transfer than a hired employee. Finally, it appears that spin-outs have a survival edge in the market over other entrants as the result of a combination of entrepreneurial flexibility and inherited knowledge. While the jury is still out on whether spin-outs are rapacious plunderers or paragons of innovation, we hope this research will trigger further research on related issues.

\section{REFERENCES}

Aldrich, H. E., \& Pfeffer, J. 1976. Environments of organizations. In A. Inkeles (Ed.), Annual review of sociology, vol. 2: 79-105. Palo Alto, CA: Annual Reviews.

Aldrich, H. E., Renzulli, L. A., \& Langton, N. 1998. Passing on privilege. Research in Social Stratification and Mobility, 16: 291-318.

Allison, P. D. 1995. Survival analysis using the SAS system: A practical guide. Cary, NC: SAS Institute.

Almeida, P., \& Kogut, B. 1999. Localization of knowledge and the mobility of engineers in regional networks. Management Science, 45: 905-917.

Anton, J. J., \& Yao, D. A. 1995. Start-ups, spin-offs, and internal projects. Journal of Law, Economics, and Organization, 11: 362-378.

Arrow, K. 1962. Economic welfare and the allocation of resources for invention. In National Bureau of Economic Research, The rate and direction of economic activity: 609-625. Princeton, NJ: Princeton University Press.

Bahk, B. H., \& Gort, M. 1993. Decomposing learning by doing in new plants. Journal of Political Economy, 101: 561-583.

Barney, J. B. 1991. Firm resources and sustained competitive advantage. Journal of Management, 17(1): 99120.

Benkhoff, B. 1997. A test of the HRM model: Good for employers and employees. Human Resource Management Journal, 7(4): 44-60.

Berman, S. L., Down, J., \& Hill, C. W. L. 2002. Tacit knowledge as a source of competitive advantage in the National Basketball Association. Academy of Management Journal, 45: 13-31.

Bhide, A. V. 2000. The origin and evolution of new businesses. Oxford, England: Oxford University Press.

Blumberg, B. F., \& Pfann, G. A. 2001. Social capital and the uncertainty reduction of self-employment. Working paper, University of Maastricht, Limburg.

Boeker, W. 1997. Executive migration and strategic change: The effect of top manager movement on product-market entry. Administrative Science Quarterly, 42: 213-236.
Braun, E., \& MacDonald, S. 1978. Revolution in miniature. Cambridge, England: Cambridge University Press.

Brav, A., \& Gompers, P. A. 1997. Myth or reality? The long-run underperformance of initial public offerings: Evidence from venture and non venture capital-backed companies. Journal of Finance, 52: 1791-1821.

Brittain, J. W., \& Freeman, J. 1980. Organizational proliferation and density-dependent selection. In J. Kimberly \& R. Miles (Eds.), Organizational life cycles: 291-338. San Francisco: Jossey-Bass.

Brittain, J. W., \& Freeman, J. 1986. Entrepreneurship in the semiconductor industry. Paper presented at the annual meeting of the Academy of Management, Dallas.

Bruderl, J., Preisendorfer, P., \& Ziegler, R. 1992. Survival chances of newly founded business organizations. American Sociological Review, 57: 227-242.

Burton, M. D., Sorensen, J. B., \& Beckman, C. M. 2002. Coming from good stock: Career histories and new venture formation. In M. Lounsbury \& M. J. Ventrasca (Eds.), Research in the sociology of organizations, vol. 19: 229-262. New York: Elsevier Science.

Carland, J. W., Carland, J. A., \& Stewart, W. H. 1996. Seeing what's not there: The enigma of entrepreneurship. Journal of Small Business Strategy, 7(1): 1-20.

Carroll, G. R., Bigelow, L. S., Seidel, M. L., \& Tsai, L. B. 1996. The fates of de novo and de alio producers in the American automobile industry 1885-1981. Strategic Management Journal, 17: 117-137.

Chandy, R. K., \& Tellis, G. J. 1998. Organizing for radical product innovation: The overlooked role of willingness to cannibalize. Journal of Marketing Research, 35: 474-487.

Chandy, R. K., \& Tellis, G. J. 2000. The incumbent's curse? Incumbency, size, and radical product innovation. Journal of Marketing, 64(3): 1-17.

Christensen, C. 1993. The rigid disk drive industry: A history of commercial and technological turbulence. Business History Review, 67: 531-588.

Christensen, C. 1997. The innovator's dilemma: When new technologies cause great firms to fail. Boston: Harvard Business School Press.

Coff, R. W. 1997. Human assets and management dilemmas: Coping with hazards on the road to resourcebased theory. Academy of Management Review, 22: $374-402$.

Cohen, W. M., \& Levinthal, D. A. 1990. Absorptive capacity: A new perspective on learning and innovation. Administrative Science Quarterly, 35: 128-152.

Conner, K. R., \& Prahalad, C. K. 1996. A resource-based theory of the firm: Knowledge versus opportunism, Organization Science, 7: 477-501. 
Cyert, R. M., Kumar, P., \& Williams, J. R. 1993. Information, market imperfections and strategy. Strategic Management Journal, 14: 47-58.

Daneels, E. 2002. The dynamics of product innovation and firm competences. Strategic Management Journal, 23: 1095-1121.

Davenport, T. H., \& Prusak, L. 1998. Working knowledge: How organizations manage what they know. Cambridge, MA: Harvard Business School Press.

Davis, G. S. 1991. Agents without principles? The spread of the poison pill through the intercorporate network. Administrative Science Quarterly, 36: 583-613.

Dess, G. G., \& Shaw, J. D. 2001. Voluntary turnover, social capital, and organizational performance. Academy of Management Review, 26: 446-456.

DiMaggio, P. M., \& Powell, W. W. 1983. The iron cage revisited: Institutional isomorphism and collective rationality in organizational fields. American Sociological Review, 48: 147-160.

Drucker, P. 1985. Innovation and entrepreneurship. New York: Harper \& Row.

Eisenhardt, K. M. 1989. Making fast strategic decisions in high-velocity environments. Academy of Management Journal, 32: 543-577.

Fiol, C. M. 1991. Managing culture as a competitive resource: An identity-based view of sustainable competitive advantage. Journal of Management, 17 (March): 191-211.

Fisher, R. J., Maltz, E., \& Jaworski, B. J. 1997. Enhancing communication between marketing and engineering: The moderating role of relative functional identification. Journal of Marketing, 61: 54-70.

Franco, A. M., \& Filson, D. 2000. Knowledge diffusion through employee mobility. Working paper, University of Iowa, Iowa City.

Garvin, D. A. 1983. Quality on the line. Harvard Business Review, 61(5): 65-75.

Gimeno, J., Folta, T. B., Cooper, A. C., \& Woo, C. 1997. Survival of the fittest: Entrepreneurial human capital and the persistence of underperforming firms. Administrative Science Quarterly, 42: 750-783.

Golder, P. N., \& Tellis, G. J. 1993. Pioneer advantage: Marketing logic or marketing legend? Journal of Marketing Research, 30: 158-170.

Gompers, P. A., \& Lerner, J. 2001. Money of invention: How venture capital creates new wealth. Boston: Harvard Business School Press.

Gort, M., \& Klepper, S. 1982. Time paths in the diffusion of product innovations. Economic Journal, 92: 630-653.

Granovetter, M. 1985. Economic action and social structure: The problem of embeddedness. American Journal of Sociology, 91: 481-510.

Grant, R. M. 1996. Toward a knowledge-based theory of the firm. Strategic Management Journal, 17(summer special issue): 109-122.

Greve, H. R. 1998. Performance, aspirations, and risky organizational change. Administrative Science Quarterly, 43: 58-86.

Griffin A., \& Hauser, J. R. 1996. Integrating R\&D and marketing: A review and analysis of the literature. Journal of Product Innovation Management, 13: 191-215.

Hannan, M. T., \& Freeman, J. 1986. Where do organizational forms come from? Sociological Forum, 1: 50-57.

Hatch, N. W., \& Macher, J. T. 2002. Mitigating the tradeoff between time-to-market and manufacturing performance: Knowledge management in new technologies. Working paper, Brigham Young University, Provo, Utah.

Haveman, H. A. 1992. Between a rock and a hard place: Organizational change and performance under conditions of fundamental environmental transformation. Administrative Science Quarterly, 37: 48-75.

Helfat, C. E., \& Lieberman, M. B. 2002. The birth of capabilities: Market entry and the importance of pre-history. Industrial and Corporate Change, 11: 725-760.

Henderson, A. D. 1999. Firm strategy and age dependence: A contingent view of the liability of newness, adolescence, and obsolescence. Administrative Science Quarterly, 44: 281-314.

Higgins, M., \& Gulati, R. 2003. Getting off to a good start: The effects of the upper echelon affiliations on underwriter prestige. Organization Science, 14: 244-263.

Hitt, M. A., Bierman, L., Shimizu, K., \& Kochhar, R. 2001. Direct and moderating effects of human capital on strategy and performance in professional service firms: A resource-based perspective. Academy of Management Journal, 44: 13-28.

Hitt, M. A., Ireland, D. R., Camp, S. M., \& Sexton, D. L. 2001. Guest editors' introduction to the special issue: Strategic entrepreneurship: Entrepreneurial strategies for wealth creation. Strategic Management Journal, 22: 479-491.

Huber, G. P. 1991. Organizational learning: The contributing processes and the literatures. Organization Science, 2: 88-115.

Inzerille, G., \& Rosen, M. 1983. Culture and organizational control. Business Research, 17: 281-292.

Jaworski, B. J., \& Kohli, A. K. 1993. Market orientation: Antecedents and consequences. Journal of Marketing, 57(7): 53-71.

Kahneman, D., \& Tversky, A. 1979. Prospect theory: An analysis of decision under risk. Econometrica, 47: 263-291.

Kamien, M., \& Schwartz, N. 1982. Market structure and innovation. New York: Cambridge University Press.

King, A. A., \& Tucci, C. L. 2002. Incumbent entry into new market niches: The role of experience and man- 
agerial choice in the creation of dynamic capabilities. Management Science, 48: 171-186.

Klepper, S. 2001. Employee startups in high-tech industries. Industrial and Corporate Change, 10: 639-674.

Klepper, S., \& Simons, K. L. 2000. Dominance by birthright: Entry of prior radio producers and competitive ramifications in the U.S. television receiver industry. Strategic Management Journal, 21: 997-1016.

Klepper, S., \& Sleeper, S. 2000. Entry by spin-offs. Working paper, Carnegie Mellon University, Pittsburgh.

Knight, R. M. 1989. Technological innovation in Canada: A comparison of independent entrepreneurs and corporate innovators. Journal of Business Venturing, 4: 281-288.

Kogut, B., \& Zander, U. 1992. Knowledge of the firm, combinative capabilities, and the replication of technology. Organization Science, 3: 383-397.

Leiponen, A. 2003. Core complementarities of the corporation: Organization of an innovating firm. Working paper, Cornell University, Ithaca, NY.

Lenox, M., \& King, A. 2003. Absorptive capacity, information provision, and the diffusion of practices within firms. Working paper, New York University, New York.

Lepak, D. P., \& Snell, S. A. 1999. The human resource architecture: Toward a theory of human capital allocation and development. Academy of Management Review, 24: 31-48.

Lerner, J. 1997. An empirical exploration of a technology race. RAND Journal of Economics, 28: 228-247.

Lieberman, M., \& Montgomery, D. 1998. First-mover (dis)advantages: Retrospective and link with the resource-based view. Strategic Management Journal 19(12): 1111-1125.

Liebeskind, J. P. 1996. Knowledge, strategy, and the theory of the firm. Strategic Management Journal, 17: 93-107.

McGrath, R. G., \& MacMillan, I. 2000. The entrepreneurial mindset. Boston: Harvard Business School.

McKenzie, K. J., \& Thompson, A. J. 1997. Taxes, the cost of capital, and investment: A comparison of Canada and the United States. Working paper 97-03, Technical Committee on Taxation, Department of Finance, Ottawa.

Meek, V. 1988. Organizational culture: Origins and weaknesses. Organization Studies, 9: 453-473.

Mitchell, W. 1991. Dual clocks: Entry order influences on incumbent and newcomer market share and survival when specialized assets retain their value. Strategic Management Journal, 12: 85-100.

Moran, P., \& Ghoshal, S. 1999. Markets, firms, and the process of economic development. Academy of Management Review, 24: 390-412.

Moriarty, R. T., \& Kosnik, T. J. 1989. High-tech market- ing: Concepts, continuity, and change. Sloan Management Review, 30(4): 7-17.

Narver, J. C., \& Slater, S. F. 1990. The effects of a marketing orientation on business profitability. Journal of Marketing, 54(10): 20-35.

Nelson, R. R., \& Winter, S. G. 1982. An evolutionary theory of economic change. Cambridge, MA: Harvard University Press.

Nonaka, I. 1994. A dynamic theory of organizational knowledge creation, Organization Science, 5(1): 14-38.

Pfeffer, J., \& Leblebici, H. 1973. Executive recruitment and the development of interfirm organizations. Administrative Science Quarterly, 18: 449-461.

Phillips, D. J. 2002. A genealogical approach to organizational life chances: The parent-progeny transfer among Silicon Valley law firms, 1946-1996, Administrative Science Quarterly, 47: 474-506.

Podolny, J. M. 1994. Market uncertainty and the social character of economic exchange. Administrative Science Quarterly, 39: 458-483.

Podolny, J. M., \& Stuart, T. E. 1995. A role-based ecology of technological change: American Journal of Sociology, 100: 1224-1260.

Prahalad, C. K., \& Bettis, R. A. 1986. The dominant logic: A new linkage between diversity and performance, Strategic Management Journal, 7: 485-502.

Roberts, E. 1991. Entrepreneurs in high technology: Lessons from MIT and beyond. New York: Oxford University Press.

Romanelli, E. 1991. The evolution of new organizational forms. In J. Blake \& W. R. Scott (Eds.), Annual review of sociology, vol. 17: 79-103. Palo Alto, CA: Annual Reviews.

Rosenbloom, R. S., \& Christensen, C. M. 1994. Technological discontinuities, organizational capabilities, and strategic commitments. Industrial and Corporate Change, 3: 655-985.

Sastry, A., \& Coen, C. 2000. Beyond the beginning: Building a theory of organizational imprinting. Working paper, University of Michigan, Ann Arbor.

Schumpeter, J. A. 1934. The theory of economic development. Cambridge, MA: Harvard University Press.

Shane, S. 2000. Prior knowledge and the discovery of entrepreneurial opportunities. Organization Science, 11: 448-469.

Shane, S., \& Khurana, R. 1999. Career experiences and firm foundings. Working paper, Sloan School of Management, Massachusetts Institute of Technology, Cambridge.

Shane, S., \& Stuart, T. 2002. Organizational endowments and the performance of university start-ups. Management Science, 48(1): 154-170.

Shane, S., \& Venkataraman, S. 2000. The promise of 
entrepreneurship as a field of research. Academy of Management Review, 25: 217-226.

Shepherd, D. A. 1999. Venture capitalists' assessment of new venture survival. Management Science, 45: 621-632.

Shrader, R. C., \& Simon, M. 1997. Corporate versus independent new ventures: Resource, strategy, and performance differences. Journal of Business Venturing, 12: 47-66.

Stinchcombe, A. L. 1965. Social structure and organizations. In J. G. March (Ed.), Handbook of organizations: 153-193. Chicago: Rand McNally.

Stinchcombe, A. L., \& Heimer, C. A. 1988. Interorganizational relations and careers in computer software firms. In I. H. Simpson \& R. L. Simpson (Eds.), Research in the sociology of work, vol. 5: 179-204. Greenwich, CT: JAI Press.

Stuart, T. E., Hoang, H., \& Hybels, R. C. 1999. Interorganizational endorsements and the performance of entrepreneurial ventures. Administrative Science Quarterly, 44: 315-349.

Szulanski, G. 1996. Exploring internal stickiness: Impediments to the transfer of best practice within the firm. Strategic Management Journal, 17(special issue): $27-43$.

Szulanski, G. 2000. The process of knowledge transfer: A diachronic analysis of stickiness. Organizational Behavior and Human Decision Processes, 82: 9-27.

Teece, D. J. 1986. Profiting from technological innovation: Implications for integration, collaboration, licensing, and public policy. Research Policy, 15: 285-305.

Teece, D. J. 1988. Capturing value from technological innovation: Integration, strategic partnering, and licensing decisions. Interfaces, 18(May-June): 46-61.

Teece, D., \& Pisano, G. 1994. The dynamic capabilities of firms: An introduction. Industrial and Corporate Change, 3: 537-556.

Teece, D. J., Pisano, G., \& Shuen, A. 1997. Dynamic capabilities and strategic management. Strategic Management Journal, 18: 509-533.

Thompson, J. D. 1967. Organizations in action: Social science bases of administrative theory. New York: McGraw-Hill.

Tushman, M. L., \& Anderson, P. 1986. Technological discontinuities and organizational environments. Administrative Science Quarterly, 31: 439-465.

Venkataraman, S. 1997. The distinctive domain of entrepreneurship research: An editor's perspective. In J. K. R. Brockhaus (Ed.), Advances in entrepreneurship, firm emergence, and growth: 119-138. Greenwich, CT: JAI Press.

von Hippel, E. 1994. "Sticky information" and the locus of problem solving: Implications for innovation. Management Science, 40: 429-439.
Wernerfelt, B. 1984. A resource-based view of the firm. Strategic Management Journal, 5: 171-180.

Whitehead, A. N. 1929. The aims of education and other essays, New York: Macmillan.

Wiggins, S. N. 1995. Entrepreneurial enterprises, endogenous ownership, and the limits to firm size. Economic Inquiry, 33: 54-69.

Winter, S. G. 1991. On Coase, competence, and the corporation. In O. E. Williamson \& S. G. Winter (Eds.), The nature of the firm: Origins, evolution and development: 179-195. Oxford, England: Oxford University Press.

Yli-Renko, H., Autio, E., \& Sapienza, H. 2001. Social capital, knowledge acquisition, and knowledge exploitation in young technology-based firms. Strategic Management Journal, 22: 587-613.

Zahra, S., \& Dess, G. 2001. Entrepreneurship as a field of research: Encouraging dialogue and debate. Academy of Management Review, 26: 8-10.

Zahra, S. A., Ireland, R. D., \& Hitt, M. A. 2000. International expansion by new venture firms: International diversity, mode of market entry, technological learning, and performance. Academy of Management Journal, 43: 925-950.

Zucker, L. G., Darby, M. R., \& Brewer, M. B. 1998. Intellectual human capital and the birth of US biotechnology enterprises. American Economic Review, 88: 290-306.

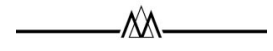

Rajshree Agarwal (agarwalr@uiuc.edu) is an associate professor of Strategic Management at the University of Illinois at Urbana-Champaign. She received her Ph.D. in economics from the State University of New York at Buffalo. Her current research interests include evolution of new product innovations, entrepreneurship, knowledge transfer, and dynamics of technological competition.

Raj Echambadi is an associate professor of marketing at the University of Central Florida. His current research interests focus on the management of innovations, management of customer relationships, and marketing research methods issues.

April Franco is an assistant professor of economics at the University of Iowa. Her Ph.D. is in economics from the University of Rochester. Her current research interests include industry dynamics, knowledge diffusion, and learning within organizations.

MB Sarkar (Ph.D., Michigan State University) is an assistant professor of strategy at the University of Central Florida. His research interests focus on entrepreneurship, technology strategy, and interorganizational alliances.

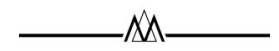


Copyright of Academy of Management Journal is the property of Academy of Management and its content may not be copied or emailed to multiple sites or posted to a listserv without the copyright holder's express written permission. However, users may print, download, or email articles for individual use. 